\title{
correspondence
}

\section{Class structure in science}

SIR, - To be castigated in a leader column is for me a unique and not entirely pleasant experience, but one which, given the choice, I would rather have had for something I did say than for something I did not say.

In talking to the Research and Development Society on April 27 I was careful to say that I did not believe simple direction was the right way to harness the resources of university science to our national objectives. I made no suggestion that (to quote your leader) "research funding in universities should be approved only if the research has clear economic benefit". Nor did I say that "individual universities should be designated as centres of expertise for certain industrial research purposes".

I emphasized that to benefit more directly from university science was essentially a matter of changing the traditional attitudes towards research of other than the very pure kind, and said in this connection that it "would help, perhaps, as a conditioning mechanism, if all applications for funds for academic research were required to state what would come from its successful completion, with the words 'a better understanding of' or any paraphrase of those words banned". No question here of "clear economic benefit" or approval based on such a concept-just a suggestion that clear thinking about where a project fits into the scheme of things would help the attitude-changing process. My mention of banning the phrase "a better understanding of" was a half-humorous reference (well understood by the audience, in which research management was fairly strongly represented) to the fact that such a phrase is the resort of nearly all woolly proposal writers.

In suggesting that we might consider allocating a major interest area to each academic institution I was not thinking of industrial research and made no mention of it. The examples I gave of the kind of theme institutions might tackle were very broad divisions of our national life and the objects of the suggestion were

- to ensure that all aspects of our communal existence were being thought about

- to gencratc groups of pcople of different disciplines sharing a common interest in an important national theme.

A journal like Nature which is looked upon as the epitome of scientific accuracy has a special duty to be certain of its facts. If there is a class war in science (which I doubt), your role, $\mathrm{Sir}$, is that of agent provocateur.

I presented my talk not as a means of expounding specific proposals but to help in generating serious discussion on a vital topic. Your handling of it will almost certainly be prejudicial to that objective, but if any of your readers would like to know what I actually said I shall be happy to send them a copy. I will even send one to you, Sir, if you are interested in fact rather than fiction.

Tewkesbury, UK

M. K. MCQuillan

\section{Frozen mineral waters}

SiR,--In his article (March 18, page 182) Allan Piper makes it clear that as soon as the exploitation of the mineral wealth of Antarctica becomes a commercial proposition there will be a major political conflict. Surely the way to handle this situation is to tackle the problem now, while the commercial issues are still relatively remote. Yet I am very much afraid that the temptation will be to postpone any resolution of the situation until the problem arises, by which time it will, of course, be too late to avoid direct confrontation and very probably military intervention.

I believe that action is necessary now to defuse this situation; for example by an agreement to sign over all mineral rights on the continent to the United Nations Organisation. It is to be hoped that signatories to the Antarctic Treaty will not sidestep the issue at their meetings this year and next.

University of Bristol, $U K$

$$
\text { J. A. EAdes }
$$

\section{Allergic reactions}

SIR,- - Reports that animal handlers are allergic to laboratory strains of rats, mice and rabbits are bccoming increasingly $\mathrm{prevalent}$ (Correspondence, March 25, page 280). In the pages of Nature and Science, the problem has been considered only from the human point of view; we bemoan the fact that many of our collcagues must either walk around with gauze masks or gulp antihistamines in order to survive their experimental subjects. We suggest that the time has come to view the in- creased number of allergic reactions from the murine rather than human perspective. The rat is evolving; we are the catalysts speeding its evolution.

Consider an animal handler approaching a colony of rats, to some of whom he or she is allergic. Is it not natural for the handler to select for experimentation only those animals who do not cause an allergic reaction? Faced with a roomful of rats, who of us would willingly choose the rat which caused our eyes to tear, our nose to drip or our bronchi to constrict. We are selectively destroying non-allergenic animals leaving behind the allergenic to act as breeders. One can see additional problems arising in the future. Rats and mice are usually picked up by the tail. Just as selection for super-allergenic strains increases the rat's chances of survival, so does selection for the short-tailed or tailless rat.

If we must root around in the rats' cage for five minutes just to find his tail, we suspect that we'll either move to the next cage or suffer a bitten finger. In short, the super-allergenic, tailless rat is a problem only for the experimenter; from inside the cage it will undoubtedly be greeted with chuckles or cheers.

JACK A. KORNBLATT

MARY JUdith KoRnblatT

Concordia University,

Montreal, Canada

\section{Human anatomy}

Sir,- Your correspondent Anthony B. Harris (May 6th, page 10) describes his "experiments" on young ladies purporting to determine a functional basis for structural asymmetry. His results, which suggest to him a positive correlation between handedness and asymmetry, are at complete variance with our observations on a thousand normal individuals, although asymmetry is certainly the rule rather than the exception.

Since Anthony Harris' measurements are all of circumference or volume, this may account for his inability to detect equivalent asymmetries in the two-dimensional representations of the human form to be found in the National Gallery; these asymmetrics, however, are observable in sculpture of many centurics and cultures.

R. C. CONNOI,L,Y

P. H. Dangerfiei.I)

University of Liverpool, UK 